\title{
Review
}

\section{Axonal Regeneration of Fish Optic Nerve after Injury}

\author{
Toru Matsukawa, ${ }^{a, c}$ Kunizo Arai, ${ }^{a, b, c}$ Yoshiki Koriyama, ${ }^{a, c}$ Zhongwu Liv, ${ }^{a}$ and Satoru Kato ${ }^{*, a, c}$ \\ ${ }^{a}$ Department of Molecular Neurobiology, Graduate School of Medicine, Kanazawa University; ${ }^{b}$ Laboratory of Molecular and \\ Cellular Physiology, Faculty of Pharmaceutical Sciences, Kanazawa University; 13-1 Takara-machi, Kanazawa, \\ Ishikawa 920-8640, Japan: and ${ }^{c}$ CREST. \\ Received December 10, 2003
}

\begin{abstract}
Since Sperry's work in the 1950s, it has been known that the central nervous system (CNS) neurons of lower vertebrates such as fish and amphibians can regenerate after axotomy, whereas the CNS neurons of mammals become apoptotic after axotomy. The goldfish optic nerve $(\mathrm{ON})$ is one of the most studied animal models of CNS regeneration. Morphological changes in the goldfish retina and tectum after $O N$ transection were first researched in the 1970s-1980s. Many biochemical studies of neurite outgrowth-promoting substances were then carried out in the 1980s-1990s. Many factors have been reported to be active substances that show increased levels during fish ON regeneration, as shown by using various protein chemistry techniques. However, there are very few molecular cloning techniques for studying $O N$ regeneration after injury. In this review article, we summarize the neurite outgrowth-promoting factors reported by other researchers and describe our strategies for searching for $\mathrm{ON}$ regenerating molecules using a differential hybridization technique in the goldfish visual system. The process of goldfish ON regeneration after injury is very long. It takes about half a year from the start of axonal regrowth to complete restoration of vision. The process has been classified into three stages: early, middle and late. We screened for genes with increased expression during regeneration using axotomized goldfish retinal and tectal cDNA libraries and obtained stage-specific cDNA clones that were upregulated in the retina and tectum. We further discuss functional roles of these molecules in the regeneration processes of goldfish $\mathrm{ON}$.
\end{abstract}

Key words goldfish; optic nerve regeneration; axon guidance molecule; upregulated gene; retina; tectum

In the adult mammalian central nervous system (CNS), axonal injury leads to retrograde neuronal degeneration and death in cell soma. ${ }^{1,2)}$ For instance, transection of the rat optic nerve $(\mathrm{ON})$ induces cell death of retinal ganglion cells (RGCs) within 2 weeks. ${ }^{3,4)}$ In contrast, injury to the fish ON never leads to widely spreading death of RGCs. Goldfish regrow the axons of their RGCs towards the tectum and finally restore their vision, even after ON transection. ${ }^{5,6)}$

It has been shown that some rat RGCs can regenerate their axons through peripheral nerve grafts. ${ }^{7)}$ This result implies that the inability of CNS neurons to regenerate in mammals is mainly due to a surrounding inhibitory environment, but not to the nature of the neurons themselves. Therefore, two approaches to the reconstruction of injured ONs in mammals have been studied intensively: 1) the use of nerve grafts or transplantation of stem cells ${ }^{8-10)}$ and 2) studying the regeneration mechanism of the mammalian peripheral nervous system (PNS) and fish CNS. ${ }^{11-13)}$ Our goal here is aimed to introduce the works of goldfish ON regeneration after injury and show up the difference between fish and mammals.

Since the first description of fish ON regeneration by Sperry's group in the $1950 \mathrm{~s}$, there has been a significant increase in the understanding of morphological changes in RGCs and factors which promote neurite outgrowth in optic axons after $\mathrm{ON}$ transection. In contrast, there is little knowledge regarding the molecular (genetic) mechanisms and cellular signaling pathways involved in fish $\mathrm{ON}$ regeneration after injury. Very recently, we apply a molecular cloning technique to find out $\mathrm{ON}$ regenerating molecules in goldfish after nerve injury. We obtain cDNA clones that are upregulated in the fish retina and tectum during $\mathrm{ON}$ regeneration. In this article, we review the neurite outgrowth-promoting factors reported by other investigators and our strategies for searching $\mathrm{ON}$ regenerating molecules in the goldfish visual system after injury.

\section{MORPHOLOGICAL ASPECTS OF FISH ON REGENER-} ATION

In goldfish, unmyelinated sproutings occur at the cut end of the ON within $3 \mathrm{~d}$, and then bundles of $20-30$ axonal sproutings penetrate into the cutting edge by $6 \mathrm{~d}$ after $\mathrm{ON}$ lesion. ${ }^{14)}$ Outgrowth of the leading axons proceeds at $0.3 \mathrm{~mm} / \mathrm{d}$ after axotomy. ${ }^{15)}$ The regenerating fibers first reach the optic lobe at $10-12 \mathrm{~d}$ after $\mathrm{ON}$ lesion, and the plexiform layer formed by the regenerating fibers is visible in all areas of the optic tectum at $14-18 \mathrm{~d}$ after $\mathrm{ON}$ lesion. ${ }^{16)}$ Although the retinotectal connection is formed $20-40 \mathrm{~d}$ after ON section, the regenerated retinotectal projection lacks topographic order for up to $40 \mathrm{~d}$. Thereafter, the retinotectal topography slowly improves over several months. ${ }^{17}$ Thus, the retinotectal connection is initially very rough and then becomes very refined after a long time. This refinement process of the regenerating fibers can be traced using local injections of wheat germ agglutinin conjugated to horse radish peroxidase (WGA-HRP) in the retina. After goldfish ON crush, a small number of optic fibers in the ventronasal retina are labeled with HRP and the distribution of labeled synapses in the tectum is examined by electron microscopy. Three weeks after crush, the labeled synapses are only observed at the far anterior end and none are seen at the correct posterior portion of the tectum. After 4 to 5 weeks, synapses are seen in almost equal numbers at incorrect and correct areas of tectum and after 12 months, synapses are restricted to the correct posterior portion. ${ }^{18)}$ In addition to the long refinement period for optic fibers in the tectum after ON injury, there is an abnormality in the RGC soma in the retina. The size of the RGC soma with dense nucleoli increases after $\mathrm{ON}$ transection. The phenomenon is known to be a cellular response to regenerating neurons after injury. ${ }^{19)}$ This hypertrophy of RGCs starts at $10 \mathrm{~d}$ and continues for $3-4$ months after axotomy. ${ }^{20)} \mathrm{We}$ 
further show that not only the soma, but also the principal processes of RGCs, become hypertrophic after axotomy. In fact, the diameter of the $\mathrm{ON}$ distal to the lesion increases four-fold during the first three months and then returns to a normal size within another three months. ${ }^{21)}$ In the tectum, myelinated optic axons decrease for the first $30 \mathrm{~d}$ after $\mathrm{ON}$ crush, and then increase and take nine months or more to return to normal levels. ${ }^{22)}$ On the other hand, fish RGCs survive during this period and become hypertrophic after $\mathrm{ON}$ injury. This is mainly due to acceleration of survival signals and inhibition of proapoptotic signals in the fish RGCs (Homma and Koriyama, submitted).

To summarize this section: Mammalian RGCs must die within a short time after ON injury, whereas fish RGCs do not die for a long time but also become hypertrophic after ON injury. A neurotracing technique with HRP reveals that regenerating axons of fish $\mathrm{ON}$ start to regrow at $7 \mathrm{~d}$ and massive axons reach to the tectum at $30 \mathrm{~d}$ after axotomy. The hypertrophic RGCs with dense nucleoli can be seen for a long time 7-100 d after injury. Therefore, the hypertrophy of fish RGCs during regeneration is thought to be one for axonal outgrowth to the tectum $(7-30 \mathrm{~d})$ and another for synaptic formation, refinement and reinforcement in the tectum (40$100 \mathrm{~d})$. The hypertrophy of regenerating RGCs with dense nucleoli reflects activation of protein and RNA synthesis for both the processes.

\section{BEHAVIORAL ASPECTS OF FISH ON REGENERATION}

Fish behavior after ON injury has been monitored by many investigators in order to estimate functional regeneration after $\mathrm{ON}$ lesion. For example, response to a change in surrounding illumination recovers only $15 \mathrm{~d}$ after fish $\mathrm{ON}$ crush, however, the ability to find food and the optometric response only recovers $40 \mathrm{~d}_{\text {later. }}{ }^{23)}$ Color discrimination also recovers within $40 \mathrm{~d}$ after $\mathrm{ON}$ transection in cichlids. ${ }^{24)} \mathrm{We}$ have developed a computer image processing system $^{25,26}$ ) which can acquire the positional coordinates of goldfish moving freely in an aquarium and determine turning directions (straight, right or left). We have also made histograms allowing quantification of the interaction between pairs of goldfish (two-point distance). By using these histograms, we estimate the time course of behavioral regeneration after $\mathrm{ON}$ transection in goldfish. Control goldfish shows an equal percentage of right or left turns and maintains an upright position in a dorsoventral axis. When the $\mathrm{ON}$ of goldfish is unilaterally sectioned, the goldfish demonstrates predominant turning and slight tilting towards the intact eye. The abnormal turning and tilting behavior lasts for $10-14 \mathrm{~d}$ and then gradually decreases, returning to control behavior within one month of the unilateral $\mathrm{ON}$ transection. When the $\mathrm{ON}$ of a single goldfish is bilaterally sectioned, it does not show any preferential turning and tilting behaviors, which is similar to what is observed in control goldfish. However, the trace maps show that, after bilateral sectioning, fish prefer to cross the center of the tank, which does not occur in control fish. In control pairs, one goldfish chases the other with a fixed short two-point distance. However, in pairs of goldfish with bilateral ON transection, the blind goldfish behave independently of each other, with a long two-point distance. The long two-point distance of the blind goldfish lasts for at least two months and then slowly returns to the control two-point distance four months or more after bilateral transection (Fig. 1). Such fast and slow recovery in goldfish behaviors evoked after unilateral or bilateral ON transection may be caused by reconnection or refinement of regenerating optic axons in the fish tectum. ${ }^{27)}$

Taken in combination, the data regarding morphological changes and behavioral analyses after ON lesion suggest three stages of fish regeneration after ON injury: 1) the early stage involving acute cellular response to the ON damage and preparation for axonal elongation 0 to $7 \mathrm{~d}$ after axotomy 2 ) the middle stage consisting of axonal elongation and reconnection of optic fibers to the tectum $7-30 \mathrm{~d}$ after axotomy. 3) the late stage where synaptic formation, refinement and reinforcement occurs in the tectum $1-3$ months after the initial injury (Fig. 2).

To summarize this section: To establish an estimating system for functional regeneration after fish $\mathrm{ON}$ injury is the most important problem. We developed a computer image

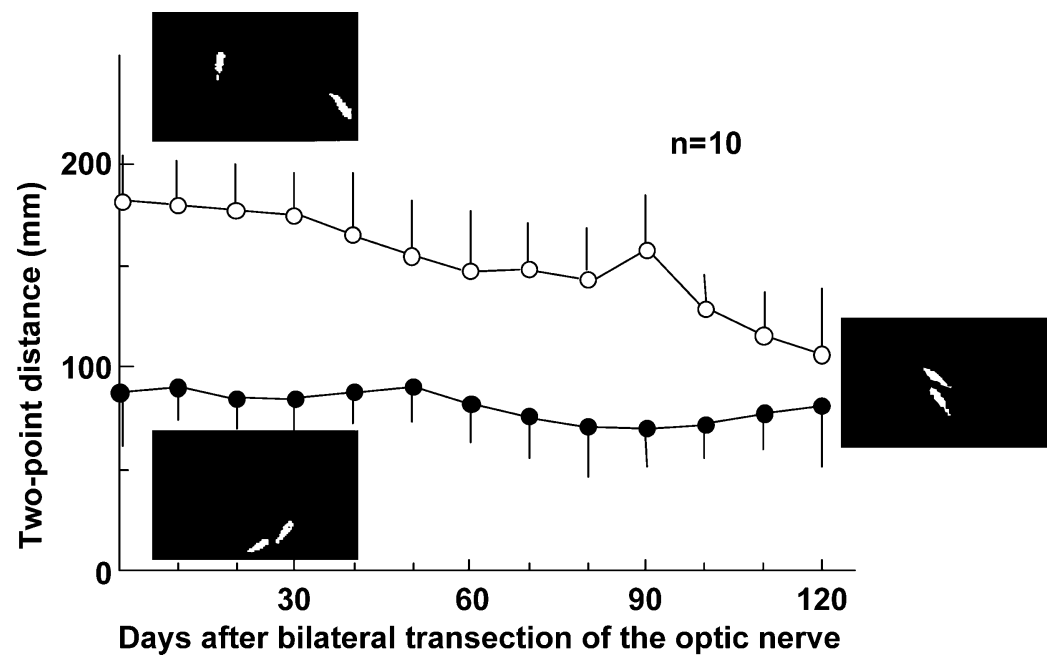

Fig. 1. Recovery Time Course of Chasing Behavior of Blind Goldfish with Bilateral ON Transection

Two-point distances of pairs of control and blind goldfish are followed using a computer image processing system. The two-point distance of blind goldfish just after ON transection is longer than that of control fish. The recovery of chasing behavior (a short two-point distance) takes more than 4 months. 
A

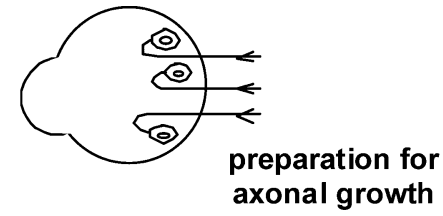

B
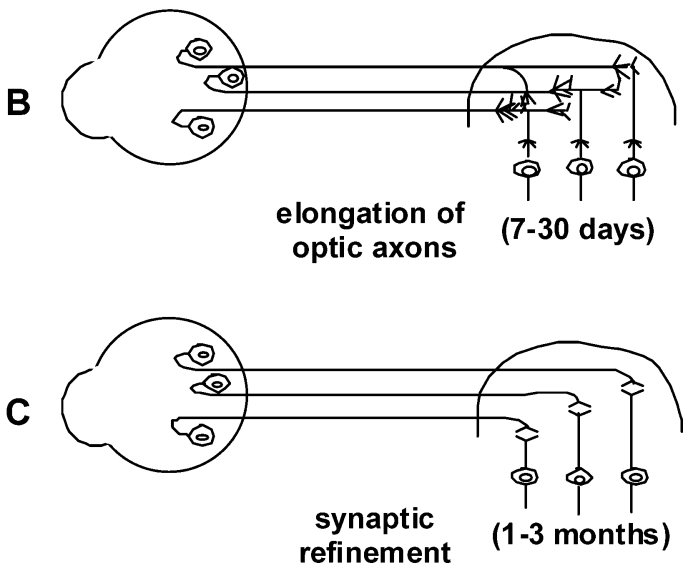

Fig. 2. The Three Stages of ON Regeneration in Goldfish after Injury

(A) First stage: preparation for axonal regrowth after axotomy. (B) Second stage: elongation and arrival at the tectum of regenerating optic axons. (C) Third stage: synaptic formation, refinement and reinforcement in the tectum of regenerating axon terminals.

processing system for goldfish and zebrafish behaviors. By comparing fish behaviors in details before and after ON transection, we can easily solve the problem. We clarify fast and slow recovery phases of goldfish behavior after ON injury. The predominant right or left turning behavior of single goldfish, which is caused by unbalance of dorsal light reflex, recovers $20-30 \mathrm{~d}$ after unilateral $\mathrm{ON}$ transection. The long two-point distance of pair of blind goldfish, which is caused by disturbance of chasing behavior, recovers $120-150 \mathrm{~d}$ after bilateral ON transection. The data strongly indicate that the fast recovery such as startle reflex and turning behavior from ON injury is accomplished by arrival of regrowing axons to the tectum and that the slow recovery such as chasing (schooling) behavior is accomplished by correct synaptic refinement of axon terminals in the tectum.

\section{BIOCHEMICAL ASPECTS OF FISH ON REGENERA- TION}

There are many reviews on neurite extension ${ }^{28-30)}$ and on axon pathfinding to the optic disk. ${ }^{31)}$ In Table 1, we list active factors whose levels are elevated after ON transection in goldfish. These factors are detected by various protein chemistry techniques such as two-dimensional electrophoresis with an in vitro culture assay system or immunohistochemical staining. As a culture system, the goldfish retina is unique. Neurite extension from the retinal explant can be seen spontaneously even in the mature goldfish retina, particularly in retinas primed by $\mathrm{ON}$ transectioning $5-7 \mathrm{~d}$ previously. Dissociated RGCs in the goldfish are also available. Therefore, estimation of neurite extension from retinal explants (RGCs) has been used as a biological assay of goldfish $\mathrm{ON}$ regeneration by many workers. ${ }^{32)}$

1) Neurotrophic Factors Nerve growth factor (NGF)
Table 1. Factors Involved in Fish ON Regeneration after Injury

\begin{tabular}{|c|c|}
\hline Neurotrophic factors & $\begin{array}{l}\text { NGF } \\
\text { CNTF } \\
\text { Axogenesis factor 1 (AF-1) } \\
\text { Axogenesis factor } 2 \text { (AF-2) }\end{array}$ \\
\hline Cell adhesion molecules & $\begin{array}{l}\text { L1 } \\
\text { N-CAM } \\
\text { Cadherin-2 } \\
\text { Cadherin-4 } \\
\text { Neurolin } \\
\text { Protein zero } \\
\text { TAG-1 }\end{array}$ \\
\hline Extracellular matrix proteins & $\begin{array}{l}\text { Laminin } \\
\text { Chondroitin sulfate proteoglycan }\end{array}$ \\
\hline Cytoskeletons & $\begin{array}{l}\text { Plasticin } \\
\text { Gefilitin } \\
\alpha 1 \text {-Tubulin } \\
\beta \text {-Thymosin }\end{array}$ \\
\hline Enzymes & $\begin{array}{l}2^{\prime}, 3^{\prime} \text {-CNPase } \\
\text { Myosin light chain kinase } \\
\text { Protein kinase C } \\
\text { NADPH diaphorase } \\
\text { Na,K-ATPase } \alpha 3\end{array}$ \\
\hline Others & $\begin{array}{l}\text { Reggie-1 } \\
\text { Reggie-2 } \\
\text { GAP-43 } \\
\text { Ephrin/Eph }\end{array}$ \\
\hline
\end{tabular}

stimulates neurite outgrowth from the priming retinal explant in culture, while anti-NGF antibody treatment significantly depresses the neurite outgrowth. ${ }^{33-35)}$ Trk-A (NGF receptor) protein and mRNA also increase in level and peak at $30 \mathrm{~d}$ after ON lesion in tench retina. ${ }^{36)}$ Ciliary neurotrophic factor (CNTF) also promotes neurite outgrowth of fish RGCs. Although other neurotrophic factors such as NT- $6,{ }^{37)}$ NT-7, ${ }^{38)}$ brain derived neurotrophic factor $(\mathrm{BDNF})^{39)}$ and glial cell line derived neurotrophic factor (GDNF ${ }^{40)}$ have been identified in fish, the functional role of these factors in $\mathrm{ON}$ regeneration is not yet known. Two low molecular weight factors (axogenesis factor 1 and 2; AF-1 and AF-2) are isolated from the goldfish $\mathrm{ON}^{41)} \mathrm{AF}-1$ is a neurite outgrowth promoting factor with potential for priming treatment of ON crush. ${ }^{42)}$ AF-1 and AF-2 are effective for neurite extension of mature rat RGCs. ${ }^{43}$

2) Cell Adhesion Molecules and Extracellular Matrix Proteins It is expected that adhesion molecules such as immunoglobulin super family proteins, for example L1, NCAM (neural cell adhesion molecule) and TAG-1 (transiently expressed axonal surface glycoprotein), participate in the extension of neurites. They promote cell aggregation and neurite extension via homophilic and heterophilic interactions. $^{29,44)}$ All axons in goldfish embryo, but only young axons in adult retina, are labeled by the monoclonal antibody E587, against L1. However, after ON transection, all RGCs in adults re-express $\mathrm{L}^{45}$ ) and the E587 antibody disturbs elongation of neurites in vitro. ${ }^{46)}$ Two L1 type molecules, L1.1 and L1.2, have been found in zebrafish, ${ }^{47)}$ and after zebrafish ON crush, axotomized adult RGCs show increased levels of L1.1 and L1.2 mRNA. ${ }^{48)}$ N-CAM is detected at marginal growth zones of the retina and tectum in normal adult goldfish, and after ON transection is detected transiently on all axons from the site of the cut into the retinore- 
cipient layers of the tectum. ${ }^{49)}$ The expression of N-CAM mRNA increases in RGCs of adult zebrafish after ON crush. ${ }^{48)} \mathrm{N}-\mathrm{CAM}$ in mammals consists of 3 isoforms of $180 \mathrm{k}, 140 \mathrm{k}$ and $120 \mathrm{k}$ proteins. The $180 \mathrm{k}$ isoform is mainly distributed in neural cells while the other two isoforms are expressed in glial cells for remyelination. ${ }^{50)}$ Three members of the N-CAM family have recently been cloned and characterized in zebrafish. ${ }^{51)}$ TAG-1 has neurite outgrowth-promoting activity. ${ }^{52)}$ This protein is expressed in nasal retinal RGCs in embryos and nasal young RGCs in adult zebrafish, and RGCs re-express TAG-1 $12 \mathrm{~d}$ after ON lesion. ${ }^{53)}$ Judging from its topographical expression pattern and period of TAG1 , it may be concerned with retinotopic organization. The proteins, L1.1, L1.2, and N-CAM are expressed not only in RGCs but also in glia cells of the $\mathrm{ON}$ and tectum. ${ }^{48)} \mathrm{N}-\mathrm{CAM}$ is also observed in the extracellular matrix. ${ }^{54)}$ Another immunoglobulin super family protein, neurolin, is expressed in all axons of goldfish embryo, and after ON transection, is expressed in retinal axons of adult goldfish. ${ }^{55,56)}$ The expression of protein zero, an immunoglobulin super family protein, increases within $2 \mathrm{~d}$ of $\mathrm{ON}$ crush in the entire optic pathway of zebrafish, and remains elevated for 6 months. ${ }^{57)}$ This protein is expressed in glia cells. Since protein zero is not well characterized, the role and significance of this protein should be further studied. Another type of cell adhesion molecule, cadherin, is important for cell-specific type interactions, and many types of cadherins have been reported. ${ }^{58)}$ In many cadherins, upregulation of cadherin-2 and -4 is reported in the adult zebrafish retina and optic pathway after ON transection. ${ }^{59)}$

Extracellular matrix proteins have been shown to influence many steps in nervous system development. ${ }^{54)}$ When one extracellular matrix protein, laminin, is used as a substratum in retinal explant culture of goldfish, neurites grow out in uncurbed spokes, and have an increased rate of elongation. ${ }^{60)}$ These results suggest that regenerating neurites have an affinity for laminin. The immunoreactivity of two extracellular matrix proteins, laminin and chondroitin sulfate proteoglycan, increases around the crush site, as well as distally. Chondroitin sulfate proteoglycan is associated with axons as well as non-neuronal cells, while laminin is only associated with non-neuronal cells. ${ }^{61)}$ Tenascin is highly expressed in embryonic RGCs undergoing axogenesis, while low levels are expressed in adult retina. After $\mathrm{ON}$ crush, expression levels remain unchanged, ${ }^{48)}$ therefore tenascin may not contribute to $\mathrm{ON}$ regeneration. This result shows that all proteins expressed during the embryonic stage are not necessarily required for adult fish $\mathrm{ON}$ regeneration.

3) Miscellaneous Molecules After ON injury, many proteins or mRNAs are reported to be induced in the retina or ON in fish, such as $2^{\prime}, 3^{\prime}$-cyclic-nucleotide $3^{\prime}$-phosphodiesterase after about $7 \mathrm{~d},{ }^{62,63)}$ myosine light chain kinase in goldfish RGCs, ${ }^{64)}$ reggie-1 and reggie-2, cell surface proteins, ${ }^{65)}$ plasticin and gefilitin, neurofilament proteins, in RGCs $10-20 \mathrm{~d}$ after ON injury in zebrafish, ${ }^{66,67)}$ GAP-43 mRNA in RGCs of zebrafish to 20 times at $5 \mathrm{~d},{ }^{68)} \alpha 1$ tubulin, ${ }^{69)}$ upregulation of protein kinase- $\mathrm{C}$ in regenerating ON fibers at $2-11$ weeks and tectum at 5 weeks in goldfish, ${ }^{70)} \beta$-thymosin, a modulator of the actin cytoskelton, mostly found in growth cone at $5-8 \mathrm{~d}$ in retina, and $4 \mathrm{~d}$ in ON of zebrafish, ${ }^{71)}$ increase of NADPH diaphorase activity in RGCs of goldfish at $5-30 \mathrm{~d},{ }^{72}$ phosphorylated microtubule associated protein $1 \mathrm{~B}$ in $\mathrm{RGCs}$ and regenerating axon. $^{73)}$

The membrane guiding molecules, the Eph family of receptor tyrosine kinase and their membrane associated ligands, ephrins, are important for precise retinotectal projections. ${ }^{74,75)}$ It is recently reported that some of these genes are activated during ON regeneration. The EphA4 receptor tyrosine kinase is necessary for the repulsive guidance of nasal retinal cell axons in vitro. ${ }^{76}$ ) Transient upregulation of the rostrocaudal gradient of ephrin A2 and ephrin A5b in goldfish tectum is also observed after ON lesion. ${ }^{77,78)}$ EphA3 and EphA5 receptor tyrosine kinases in goldfish retina are transiently upregulated, whereas ephrin A2 in the retina remains unchanged after $\mathrm{ON}$ lesion. ${ }^{79)}$

4) Myelin-Associated Inhibitory Factors for ON Regeneration One main obstacle to mammalian CNS regeneration is the presence of inhibitory factors in myelin, for example, Nogo, myelin-associated glycoprotein (Mag) and oligodendrocyte-myelin glycoprotein (Omgp) ${ }^{80,81)}$ The molecular nature of the inhibitory action of myelin is summarized in a recent review. ${ }^{82}$ The structures of fish CNS myelin sheaths and major structural glycoprotein resemble those of mammals. ${ }^{83)}$ A consensus has not yet been reached on the inhibitory activity of fish myelin. In dissociated culture of newborn rat brain neuron, the neurite extension is inhibited on the substrate prepared from rat CNS myelin fraction, but not on that prepared from trout or frog spinal cord myelin. ${ }^{84)}$ In explant culture of goldfish retina, the growth of regenerating axons from RGCs is inhibited by the presence of rat oligodendrocytes or CNS myelin, but not by oligodendrocyte-like cells prepared from goldfish $\mathrm{ON}$ and CNS myelin. ${ }^{85)}$ Fish oligodendrocytes support axonal regeneration of fish and mammalian RGCs. ${ }^{86)}$ It is known that a monoclonal antibody against Nogo, called IN-1, can be neutralized by the inhibition of neurite outgrowth. ${ }^{80}$ ) The goldfish ON lacks the molecule recognized by IN-1. ${ }^{87)}$ In contrast, Sivron et al. ${ }^{88)}$ report that there is no neuritic growth on sections of uninjured fish ON, however, many neurites are observed on the sections of ON that were crushed previously, and this nonpermissiveness of normal fish ON is broken by the IN-1 antibody. ${ }^{88)}$ It has been reported that after ON lesion, myelin disappears, and then reappears again at $21 \mathrm{~d}$. However, oligodendrocytes themselves do not seem to disappear. ${ }^{89)}$ In either case, no inhibition of fish ON myelin is obvious during regeneration.

To summarize this section: Almost all neurotrophic factors and axon-guidance molecules for fish $\mathrm{ON}$ regeneration are effective both to the fish and mammalian retinas. The fact reconfirms that the CNS neurons of mammals have an intrinsic ability to regenerate after nerve injury. On the other hand, myelin inhibitory factors and oligodendrocytes in the fish optic nerve are much different in nature from those of mammals. More detailed comparison of this line will help in solving the problem of CNS regeneration of mammals.

\section{STRATEGIES FOR SCREENING GENES UPREGU- LATED AFTER FISH ON INJURY}

Over the past twenty years, many efforts have been made to find molecules involved in regeneration after fish $\mathrm{ON}$ injury. However, these studies closely mimic the work in mam- 
mals and are very sporadic. Therefore, we started a more systematic process to discover which molecules are involved in regeneration, as using molecular cloning technique to search for genes whose expression increases after ON injury. Since the process of fish ON regeneration is classified into three stages: early, middle and late as mentioned above, we screen genes upregulated at each stage in the fish visual system. We construct retinal cDNA and tectal cDNA libraries derived from the retina or tectum 5 or $60 \mathrm{~d}$ after axotomy. The former contains molecules related to preparing and promoting optic axon elongation in the retina. The latter contains molecules related to synaptic refinement and reinforcement in the tectum.

1) Retinol-Binding Protein in the Early Stage of Fish ON Regeneration We clone a secretory retinol-binding protein (RBP) homolog to chicken purpurin ${ }^{90)}$ from the retinal cDNA library with differential hybridization of normal and axotomized retina. The RBP mRNA increases in the very early stage and is only transiently expressed. RBP mRNA peaks $2-5 \mathrm{~d}$ after axotomy. The increased mRNA localization is limited to the photoreceptor cells, but not the RGCs. Recombinant RBP alone does not induce neurite outgrowth from retinal explants, but concomitant addition with retinol induces a dramatic enhancement of neurite outgrowth. The early and transient upregulation and unusual localization of RBP mRNA indicates a priming action of this protein on triggering ON elongation (Matsukawa et al., submitted).

2) Na,K-ATPase $\alpha 3$ Subunit in the Middle Stage of Fish ON Regeneration We clone a membrane protein that is a homolog of the chicken $\mathrm{Na}, \mathrm{K}$-ATPase $\alpha 3$ subunit. Na,K-
ATPase $\alpha 3$ mRNA increases 5-30 d after ON transection, with a peak of about $10 \mathrm{~d}$ after axotomy. Additional mRNA localization is limited to the ganglion cells in the goldfish retina (Fig. 3). Furthermore, in the retinal explant culture, a low dose of ouabain, at a concentration that specifically blocks the action of $\mathrm{Na}, \mathrm{K}$-ATPase $\alpha 3$, inhibits the neurite outgrowth of RGCs. ${ }^{91)} \mathrm{Na}, \mathrm{K}$-ATPase transports sodium and potassium ions and is a heterodimer composed of $\alpha$ and $\beta$ subunits. The $\alpha$ subunit works as a catalytic domain and the $\beta$ subunit works as a stabilizing domain. The $\alpha$ subunit has 4 isoforms and the $\beta$ subunit has 2 isoforms. ${ }^{92)}$ In the rat sciatic nerve, $\alpha 3$ and $\beta 1$ isoforms completely disappear from the distal segment of the nerve after injury by Wallerian degeneration, but $\alpha 2$ and $\beta 2$ isoforms increase in Schwann cells. After that, the levels of $\alpha 3$ and $\alpha 2$ isoforms return to normal. ${ }^{93)}$ These results suggest that the $\alpha 3$ and $\beta 1$ isoforms are localized in the axons, and $\alpha 2$ and $\beta 2$ isoforms are in Schwann cells. Our retinal culture system using ouabain strongly indicates that the $\alpha 3$ isoform is localizaed to RGCs and their axons and the $\alpha 3$ isoform is involved in $\mathrm{ON}$ regeneration. Adhesion molecule on glia (AMOG) is reported to mediate neuron-astrocyte interaction in vitro, ${ }^{94)}$ and later identified as a $\beta$ subunit for Na,K-ATPase. ${ }^{95)}$ When AMOG transfected L cells are used as a substrate in culture, neurite outgrowth of cerebellar and hippocampal neurons in rodents is induced by this treatment. ${ }^{96}$,

3) Transglutaminase in the Middle Stage of Fish ON Regeneration Transglutaminase catalyzes a posttranslational modification of proteins through exchange of primary amines for ammonia at the $\gamma$-carboxyamide group of gluta-
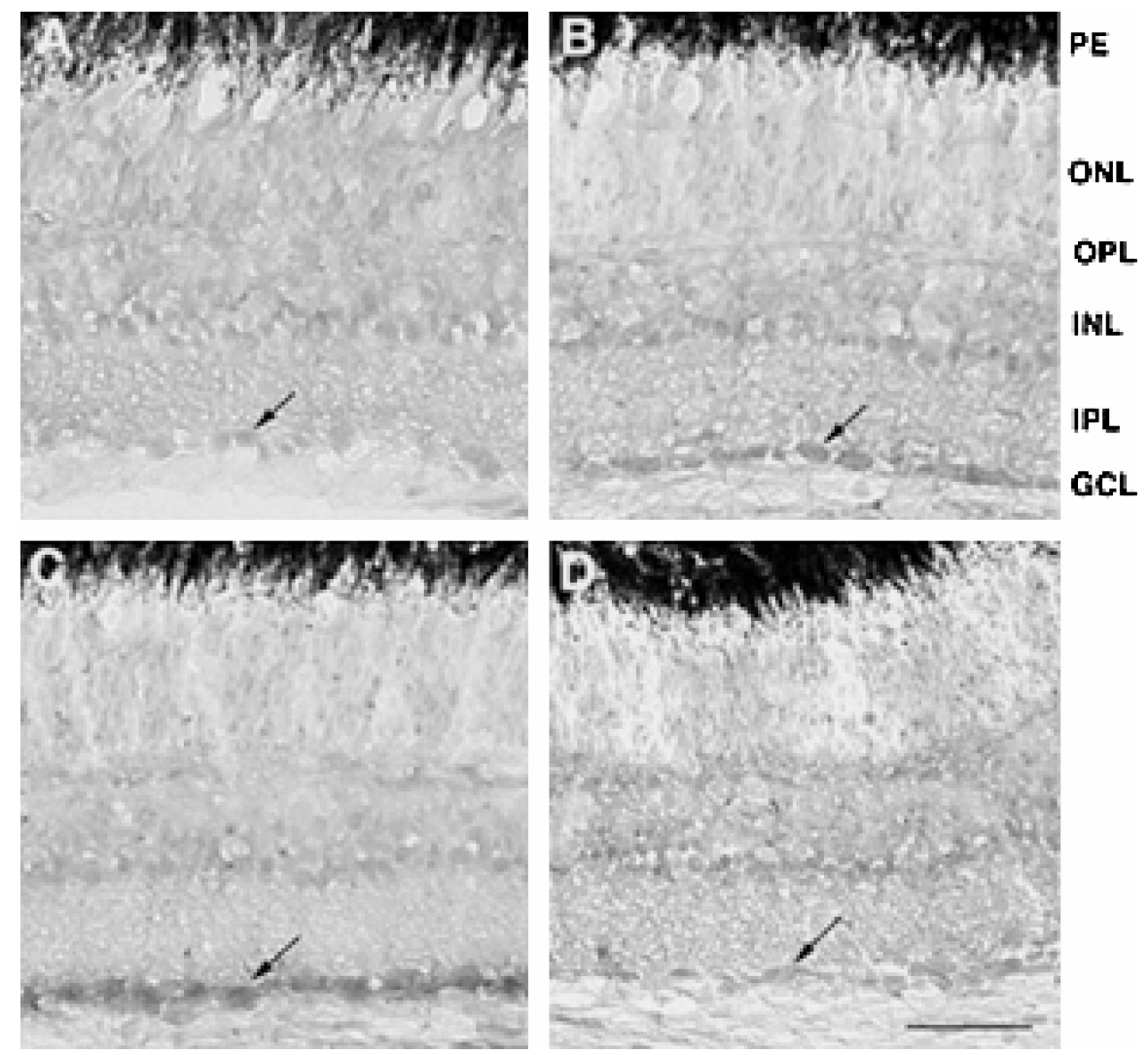

Fig. 3. In Situ Hybridization of $\mathrm{Na}, \mathrm{K}-\mathrm{ATP} a \mathrm{se} \alpha 3$ Subunit mRNA on the Goldfish Retina

(A) Low levels of Na,K-ATPase $\alpha 3$ subunit message are detected in all three layers of ONL, INL and GCL of control retina. At $5 \mathrm{~d}$ (B) and $10 \mathrm{~d}$ (C) after axotomy, the mRNA increases only in the GCL (marked with arrows). (D) The mRNA levels in the GCL decreases gradually, returning to the control level by $45 \mathrm{~d}$ after axotomy. Scale bar= $40 \mu \mathrm{m}$. 
mine residues and lysine residues of proteins or polyamines serving as primary amines. ${ }^{97)}$ Transglutaminase activity in the PNS rapidly increases after nerve injury. ${ }^{98,99)}$ We clone a retinal transglutaminase that is homologous to tissue type transglutaminase. The retinal transglutaminase mRNA increases from day 5 to day 40, peaking $20 \mathrm{~d}$ after injury. Localization of increased mRNA is limited to the RGCs. Addition of recombinant transglutaminase protein further promotes neurite outgrowth from the priming retinal explants, while neutralizing antibody against transglutaminase inhibits the neurite outgrowth of RGCs. Although we are unable to detect substrate candidates for transglutaminase, the protein linking enzyme participates in the regeneration process of PNS or CNS neurons.

4) Ferritin H-1 in the Late Stage of Fish ON Regeneration We select three clones from the tectal cDNA library containing normal and axotomized tecta treated with $\mathrm{ON}$ transection $60 \mathrm{~d}$ previously. One clone is a homolog to chicken ferritin H-1. The ferritin H-1 mRNA increases 40 $100 \mathrm{~d}$ after $\mathrm{ON}$ lesion, peaking $60 \mathrm{~d}$ after axotomy. The localization of increased mRNA is limited to the tectal neurons synapsing with optic axon terminals in the goldfish tectum. The other two clones also have a similar expression pattern or period in the tectum. The expression pattern or period of these clones strongly suggests that they participate in the synaptic refinement of excess amounts of optic axons.

To summarize this section: Some neurotrophic factor (AF1) and enzyme (transglutaminase) extracted from goldfish optic nerve after injury partially rescue rat RGCs and promote their axonal regrowth. ${ }^{43,100}$ These experimental data further stimulate us to search for regenerating molecules in the goldfish retina after ON injury. Thus, we start a molecular cloning approach to get interesting genes during fish ON regeneration. We exactly define three early, middle and late stages of fish $\mathrm{ON}$ regeneration after transection and obtain several cDNA clones which are stage-dependently upregulated. Such a molecular approach is required for elucidating the big difference of rat and fish RGCs after ON injury.

\section{CONCLUSION}

The adhesion and guidance molecules mentioned above, which are secreted from glial cells, may play a major role in the regulation of axonal growth after ON insult. This suggests that two-way dynamic communication between axons (neurons) and glial cells is implicated in axonal regeneration. The cross-talk between axons and glial cells during ON regeneration may open with: (i) glial activation by factors which are secreted by injured neurons, and then (ii) RGCs survival control and axonal outgrowth, which are influenced by glial cells, (iii) growth cone guidance, as glial cells function as route indicators, and (iv) connectivity, where an axon contacts with its final targets, aided by glial cells. As described above, the step on growth cone guidance is well elucidated, but there are few studies on neural-glial interactions at the other steps. Recently, we find that ATP, which may be released from injured neurons, stimulates neurite outgrowth in goldfish. We hypothesize that ATP causes the transformation of microglia from a resting to an activated state, and as a consequence, microglial cells produce neurotrophic and axon guiding factors. These factors support neuronal survival and promote axonal regrowth.

As compared with the study of the glial and extracellular environment in axonal regeneration, there are few reports on the intrinsic regenerative potential of RGCs. The goldfish visual system displays continuous growth and plasticity throughout life. Clarification of differences in intrinsic regenerative potential of RGCs between mammals and fish is very useful for therapeutic designs against degenerative CNS disorders.

A feature of the goldfish visual pathway that has attracted much attention is the clear point-to-point mapping (synaptic refinement) of the retina to tectum restructured after $\mathrm{ON}$ transection. Two processes are thought to build this fine retinotopic order. One is an activity-independent process of RGCs, presumed to be some form of substrate-directed growth, which generates a rough retinotopy as seen in the early projection. The other is an activity-dependent process of RGCs that constructs a fine retinotopy during a protracted period of refinement in the late projection. ${ }^{101,102)}$ Gene cloning is a very useful technique for the investigation of molecular mechanisms, both of neurite elongation and retinotectal projection after $\mathrm{ON}$ injury. The molecules cloned in our study, which are upregulated during $\mathrm{ON}$ regeneration in goldfish, will help in understanding these processes.

Acknowlegments We wish to thank Ms Tami Urano and Ms Tomoko Kano for their assistance. This study was supported in part by research grants (No. 12878134 to TM, 15922093 to YK, 02273 to ZWL, 12680750, 14034219, 14658267 to SK) from the Ministry of Education, Culture, Sports, Science and Technology Japan.

\section{REFERENCES}

1) Garcia-Valenzuela E., Gorczyca W., Darzynkiewicz Z., Sharma S. C., J. Neurobiol., 25, 431-438 (1994).

2) Schwab M. E., Bartholdi D., Physiol. Rev., 76, 319-370 (1996).

3) Bähr M., Bonhoeffer F., Trends Neurosci., 17, 473-479 (1994).

4) Villegas-Pérez M.-P., Vidal-Sanz M., Rasminsky M., Bray G. M., Aguayo A. J., J. Neurobiol., 24, 23-36 (1993).

5) Stuermer C. A. O., Bastmeyer M., Bähr M., Strobel G., Paschke K., J. Neurobiol., 23, 537-550 (1992).

6) Weise J., Ankerhold R., Bähr M., Microsc. Res. Tech., 48, 55-62 (2000).

7) David S., Aguayo A. J., Science, 214, 931-933 (1981).

8) MacLaren R. E., Eye, 13, 277-284 (1999).

9) Miller N. R., Am. J. Ophthalmol., 132, 811-818 (2001).

10) Dezawa M., Anat. Sci. Int., 77, 12-25 (2002).

11) Bernhardt R. R., Exp. Neurol., 157, 223-240 (1999).

12) Goldberg J. L., Barres B. A., Annu. Rev. Neurosci., 23, 579-612 (2000).

13) Sofroniew M. V., Howe C. L., Mobley W. C., Annu. Rev. Neurosci., 24, 1217-1281 (2001).

14) Lanners H. N., Grafstein B., J. Neurocytol., 9, 733-751 (1980).

15) McQuarrie I. G., Grafstein G., Brain Res., 216, 253-264 (1981).

16) Attardi G. A., Sperry, R. W., Exp. Neurol., 7, 46-64 (1963).

17) Meyer R. L., J. Comp. Neurol., 189, 273-289 (1980).

18) Meyer R. L., Kageyama G. H., J. Comp. Neurol., 409, 299-312 (1999).

19) Grafstein B., Exp. Neurol., 48, 32-51 (1975).

20) Devadas M., Sugawara K., Shimada Y., Sugitani K., Liu Z. W., Matsukawa T., Kato S., Neurosci. Res., 37, 289-297 (2000).

21) Murray M., J. Comp. Neurol., 209, 352-362 (1982).

22) Murray M., Edwards M. A., J. Comp. Neurol., 209, 363-373 (1982).

23) Springer A. D., Agranoff B. W., Brain Res., 128, 405-415 (1977).

24) Arora H. L., Sperry R. W., Dev. Biol., 7, 234-243 (1963).

25) Kato S., Tamada K., Shimada Y., Chujo T., Behav. Brain Res., 80, 
$51-55$ (1996).

26) Kato S., Nakagawa T., Ohkawa M., Muramoto K., Oyama O., Watanabe A., Nakashima H., Nemoto T., Sugitani, K., J. Neurosci. Meth., 134, 1-7 (2004).

27) Kato S., Devadas M., Okada K., Shimada Y., Ohkawa M., Muramoto K., Takizawa N., Matsukawa T., Neuroscience, 93, 907-914 (1999).

28) Skene J. H., Annu. Rev. Neurosci., 12, 127-156 (1989).

29) Oster S. F., Sretavan D. W., Br. J. Ophthalmol., 87, 639-645 (2003).

30) Goldberg J. L., Genes Dev., 17, 941—958 (2003).

31) Stuermer C. A. O., Bastmeyer M., Prog. Neurobiol., 62, 197-214 (2000).

32) Johns P. R., Heacock A. M., Agranoff B. W., Brain Res., 142, 531537 (1978).

33) Turner J. E., Delaney R. K., Johnson J. E., Brain Res., 204, 283-294 (1981).

34) Turner J. E., Schwab M. E., Thoenen H., Dev. Brain Res., 4, 59-66 (1982).

35) Yip H. K., Grafstein B., Brain Res., 238, 329-339 (1982).

36) Caminos E., Becker E., Martín-Zanca D., Vecino E., J. Comp. Neurol., 404, 321-331 (1999).

37) Götz R., Köster R., Winkler C., Raulf F., Lottspeich F., Schartl M., Thoenen H., Nature (London), 372, 266-269 (1994).

38) Nilsson A. S., Fainzilber M., Falck P., Ibanez C. F., FEBS Lett., 424, 285-290 (1998).

39) Hashimoto M., Heinrich G., Int. J. Dev. Neurosci., 15, 983-997 (1997).

40) Shepherd I. T., Beattie C. E., Raible D. W., Dev. Biol., 231, 420-435 (2001).

41) Schwalb J. M., Boulis N. M., Gu M.-f., Winickoffz J., Jackson P. S., Irwin N., Benowitz L. I., J. Neurosci., 15, 5514-5525 (1995).

42) Schwalb J. M., Gu M.-f., Stuermer C., Bastmeyer M., Hu G.-f., Boulis N., Irwin N., Benowitz L. I., Neuroscience, 72, 901-910 (1996).

43) Yin Y., Cui Q., Li Y., Irwin N., Fischer D., Harvey A. R., Benowitz L. I., J. Neurosci., 23, 2284-2293 (2003).

44) Burden-Gulley S. M., Pendergast M., Lemmon V., Cell Tissue Res., 290, 415-422 (1997).

45) Vielmetter J., Lottspeich F., Stuermaer C. A. O., J. Neurosci., 11, 3581-3593 (1991)

46) Bastmeyer M., Ott H., Leppert C. A., Stuermer C. A. O., J. Cell Biol., 130, 969-976 (1995).

47) Tongiorgi E., Bernhardt R. R., Schachner M., J. Neurosci. Res., 42, 547-561 (1995).

48) Bernhradt R. R., Tongiorgi E., Anzini P., Schachner M., J. Comp. Neurol., 376, 253-264 (1996).

49) Bastmeyer M., Schlosshauer B. S., Stuermer C. A. O., Development, 108, 299-311 (1990).

50) Massaro A. R., Neurol. Sci., 22, 429-435 (2002).

51) Mizuno T., Kawasaki M., Nakahira M., Kagamiyama H., Kikuchi Y., Okamoto H., Mori K., Yoshihira Y., Mol. Cell. Neurosci., 18, 119130 (2001).

52) Furley A. J., Morton S. B., Manalo D., Karagogeos D., Dodd J., Jessell T. M., Cell, 61, 157-170 (1990).

53) Lang D. M., Warren J. T., Jr., Klisa C., Stuermer C. A. O., Mol. Cell. Neurosci., 17, 398-414 (2001).

54) Reichardt L. F., Tomaselli K. J., Annu. Rev. Neurosci., 14, 531—570 (1991).

55) Paschke K. A., Lottspeich F., Stuermer C. A. O., J. Cell Biol., 117, 863 -875 (1992).

56) Laessing U., Giordano S., Stecher B., Lottspeich F., Stuermer C. A. O., Differentiation, 56, 21-29 (1994).

57) Schweitzer J., Becker T., Becker C. G., Schachner M., Glia, 41, 301-317 (2003).

58) Redies C., Prog. Neurobiol., 61, 611-648 (2000).

59) Liu Q., Londraville R. L., Azodi E., Babb G. C., ChiappiniWilliamson C., Marrs J. A., Raymond P. A., Exp. Neurol., 177, 396406 (2002).

60) Hopkins J. M., Ford-Holevinski T. S., McCoy J. P., Agranoff B. W., J. Neurosci., 5, 3030-3038 (1985)

61) Battisti W. P., Shinar Y., Schwartz M., Levitt P., Murray M., J. Neurocytol., 21, 557-573 (1992).

62) Wilmot G. R., Raymond P. A., Agranoff B. W., J. Neurosci., 13,
387-401 (1993).

63) Ballestero R. P., Wilmot G. R., Agranof B. W., Uhler M. D., J. Biol. Chem., 272, 11479-11486 (1997).

64) Jian X., Szaro B. G., Schmidt J. T., J. Neurobiol., 31, 379-391 (1996).

65) Schulte T., Paschke K. A., Laessing U., Lottspeich F., Stuermer C. A. O., Development, 124, 577-587 (1997).

66) Asch W. S., Leake D., Canger A. K., Passini M. A., Argenton F., Schechter N., J. Neurochem., 71, 20-32 (1998).

67) Niloff M. S., Dunn R. J., Levine R. L., Brain Res. Mol. Brain Res., 61, 78-89 (1998).

68) Bormann P., Zumsteg V. M., Roth L. W. A., Reinhard E., J. Neurosci. Res., 52, 405- 419 (1998).

69) Hieber V., Dai X., Foreman M., Goldman D., J. Nerobiol., 37, 429440 (1998).

70) Schmidt J. T., J. Neurobiol., 36, 315-324 (1998).

71) Roth L. W. A., Bormann P., Wiederkehr C., Reinhard E., Eur. J. Neurosci., 11, 3488-3498 (1999).

72) Devadas M., Liu Z., Kaneda M., Arai K., Matsukawa T., Kato S., Neurosci. Res., 40, 359-365 (2001).

73) Vecino E., Avila J., Brain Res. Bull., 56, 131-137 (2001).

74) Knoll B., Drescher U., Trends Neurosci., 25, 145-149 (2002).

75) McLaughlin T., Hindges R., O’Leary D. M., Curr. Opin. Neurobiol., 13, 57-69 (2003).

76) Walkenhorst J., Dütting D., Handwerker C., Huai J., Tanaka H., Drescher U., Mol. Cell. Neurosci., 16, 365-375 (2000).

77) Rodger J., Bartlett C. A., Beazley L. D., Dunlop S. A., Exp. Neurol., 166, 196-200 (2000).

78) Becker C. G., Becker T., J. Comp. Neurol., 427, 469-483 (2000).

79) King C. E., Wallace A., Rodger J., Bartlett C., Beazley L. D., Dunlop S. A., Exp. Neurol., 183, 539-599 (2003).

80) Schwab M. E., Kapfhammer J. P., Bandtlow C. E., Annu. Rev. Neurosci., 16, 565-595 (1993).

81) Filbin M. T., Nat. Rev. Neurosci., 4, 703-713 (2003).

82) Spencer T., Domeniconi M., Cao Z., Filbin M. T., Curr. Opin. Neurobiol., 13, 133-139 (2003).

83) Jeserich G., Waehneldt T. V., J. Neurochem., 46, 525-533 (1986).

84) Caroni P., Schwab M. E., J. Cell Biol., 106, 1281-1288 (1988).

85) Bastmeyer M., Beckmann M., Schwab M. E., Stuermer C. A. O., J. Neurosci., 11, 626-640 (1991).

86) Bastmeyer M., Bähr M., Stuermer C. A. O., Glia, 8, 1-11 (1993).

87) Wanner M., Lang D. M., Bandtlow C. E., Schwab M. E., Bastmeyer M. E., Stuermer C. A. O., J. Neurosci., 15, 7500-7508 (1995).

88) Sivron T., Schwab M. E., Schwartz M., J. Comp. Neurol., 343, 237246 (1994).

89) Ankerhold R., Stuermer C. A. O., J. Neurobiol., 41, 572-584 (1999).

90) Berman P., Gray P., Chen E., Keyser K., Ehrlich D., Karten H., LaCorbiere M., Esch F., Schubert D., Cell, 51, 135-142 (1987).

91) Liu Z. W., Matsukawa T., Arai K., Devadas M., Nakashima H., Tanaka M., Mawatari K., Kato S., J. Neurochem., 80, 763-770 (2002).

92) Blanco G., Mercer R. W., Am. J. Physiol., 275, F633-F650 (1998).

93) Kawai H., Yasuda H., Terada M., Omatsu-Kanbe M., Kikkawa R., J. Neurochem., 69, 330-339 (1997).

94) Antonicek H., Persohn E., Schachner M., J. Cell Biol., 104, 15871595 (1987).

95) Gloor S., Antonicek H., Sweander K. J., Pagliusi S., Frank R., Moos M., Schachner M., J. Cell Biol., 110, 165-174 (1990).

96) Müller-Husmann G., Gloor S., Schachner M., J. Biol. Chem., 268, $26260-26267$ (1993).

97) Greenberg C. S., Birckbichler P. J., Rice R. H., FASEB J., 5, 30713077 (1991)

98) Gilad G. M., Varon L. E., Gilad V. H., J. Neurochem., 44, 13851390 (1985)

99) Tetzlaff W., Gilad V. H., Leonard C., Bisby M. A., Gilad G. M., Brain Res., 445, 142-146 (1988)

100) Eitan S., Solomon A., Lavie V., Yoles E., Hirschberg D. L., Belkin M., Schwartz M., Science, 264, 1764-1768 (1994).

101) Olson M. D., Meyer R. L., J. Comp. Neurol., 303, 412-423 (1991).

102) Olson M. D., Meyer R. L., J. Comp. Neurol., 347, 481-494 (1994). 